\title{
Abortion as a Public Health Problem
}

\author{
Sebastião Junior Henrique Duarte*, Mirian Yuriko Girata and Maicon Douglas Rodrigues \\ Universidade Federal de Mato Grosso do Sul, Brazil
}

Submission: February 05, 2017 ; Published: February 28, 2017

*Corresponding author: Sebastião Junior Henrique Duarte, Universidade Federal de Mato Grosso do Sul, s/n - Unidade 9 - Cidade Universitária, Campo Grande - MS, 79070-900, Brazil, Tel: +55(67) 3345-7223; Email: sjhd.ufms@gmail.com

Abstract

In Brazil, abortion is considered a crime, with rare exceptions even abortion is one of the main causes of maternal mortality. It should be an emphasized that among the most frequent reasons for abortion are pregnancies due to rape, that is, sexual violence. This situation requires measures to combat this type of violation of the human rights of women. Another important gap that leads women to resort to abortion as a means of controlling procreation refers to the unmet needs of family planning, requiring attention by the public health system, access to more diversified methods of family planning, and reproductive care for the rational use of services that perform legal abortion, thereby reducing maternal mortality, in accordance with the commitments made by the leaders of the United Nations towards sustainable development objectives.

Keywords: Women'shealth; Sexual and reproductive health; Abortion

\section{Introduction}

In Brazil, abortion is considered a crime, except in three situations:

i. When the pregnancy presents a risk of death for the mother,

ii. When the fetus has anencephaly and

iii. Gestation due torape. Stands out that the sexual violence is the main reason for legalized abortions.

The Organization of American States has defined violence against women as any act based on gender that causes physical, sexual or psychological harm or suffering and even death, regardless of whether it occurred in the public (public place, work, etc.) or in the private (home) [1].

It is stands out that violence against women results in a public health problem throughout the world. Thus, the United Nations leaders listed the 17 sustainable development goals, where number five refers to gender equality and the empowerment of all women. Targets include: elimination of all forms of violence against all women and girls in public and private spheres, including trafficking and sexual and other forms of exploration; Ensure universal access to sexual and reproductive health and reproductive rights as agreed in accordance with the Program of Action of the International Conference on Population and
Development and the Beijing Platform for Action and the documents resulting from its review conferences [2]

The literature shows the magnitude of violence, expressed annually in 12 million people suffering from sexual violence. In the United States, the estimate is 680 thousand rapes each year, while in Brazil government statistics record 8.7 rapes per 100,000 inhabitants [3].

Abortion stemming from sexual violence against women, therefore, will continue to be a practice that puts women at risk of death who do not have access to health services. As a result, reducing maternal mortality will continue to be a challenge.

In consideration the relevance of the issue and contributing to studies that reveal the importance of public policies to address violence against women, this study aims to discuss abortion as a public health problem.

\section{The Context}

Each year, thousands of women die worldwide from the complications of abortion, which is a major cause of death in this population group, especially in developing countries.

Abortion can be a common practice even among women who have not suffered some form of sexual violence, especially when there is a lack of contraception. Except for pregnancy 
through rape, there are those unplanned pregnancies. Then there is concern that every woman has access to family planning methods, which is a resource for avoiding abortions.

In the United States, limiting access to public contraceptive services has led to unplanned pregnancies, abortions and has an impact on the infant mortality rate [4]. Brazil has a public policy of family planning aimed at ensuring sexual freedom and guaranteeing sexual and reproductive rights. However, it is questionable whether the entire population is aware of the most diverse methods of reproductive control, and whether public health services offer appropriate methods to each person $[5,6]$.

By 2015, 64\% of married women have used some contraceptive method, and about $40 \%$ of women living in developing countries use some method to control procreation. However, it is estimated that $12 \%$ of these women had unmet family planning needs. Of the total, $22 \%$ are in developing countries, and $30 \%$ or more are in the countries of Africa, Haiti \& Samoa [7].

Access to contraceptive methods is the main strategy to prevent unwanted pregnancies and reduce the number of maternal deaths related to frequent pregnancies, short birth intervals, gestational complications, and reduction of unsafe abortion $[8,9]$.

It should be noted that there are inequalities between access to family planning services and women from disadvantaged social classes, according to the Brazilian national health survey. The data call attention to the need for equity in access to the means of birth control [10].

The highest frequency of abortions was recorded in the two Brazilian regions with the lowest human development index. Therefore, it is assumed that women with low schooling are unaware of the right to public access to family planning methods, and ignorance also leads to contraceptive use, low adherence, unwanted pregnancies and the possibility of induced abortion [10].

The practice of abortion is undeniable, as emphasized in this study. Reducing the occurrence of induced abortions requires more coercive measures for sexual crimes against women, in order to reduce the number of rapes, and to ensure the human rights of women.

\section{Conclusion}

Certainly that unsafe abortion in Brazil will continue to be a maternal death and that access to family planning means and the implementation of coercive policies to combat sexual violence constitute measures to address the historical problem of women.

\section{Acknowledgement}

This article is part of the research entitled "Social representation of health professionals regarding family planning". National Counselof Technological and Scientific Development, Institutional Program of Scientific Initiation Scholarships.

\section{References}

1. Organizationof American States (195) Inter-American Convention on the Prevention, Punishment, and Eradication of Violence against Women (1995) General Assembly of the Organization of American States.

2. United Nations (2015) Sustainable Development Goals. 17 Goals to transform our world, New York, USA.

3. Drezett J, Pedroso D (2012) Abortion and sexual violence. Cienc Cult 64(2): 35-38.

4. Krieger N, Gruskin S, Singh N, Kaing M, Chen JT, etal. (2016) Reproductive justice \&preventabledeaths: Statefunding, familyplanning, abortion, andinfantmortality, US 1980-2010. SSM - Population Health 2: 277293.

5. Brazil (1986) Federal Law $n^{\circ} 9263 / 1986$. Regulates paragraph 7 of art. 226 of the Federal Constitution, which deals with family planning, establishes penalties and gives other measures. Official Journal of Federative Republic of Brazil.

6. Brazil (2016) NationalCommission for thein corporation of Technologies in public health sistem. Ordinance ${ }^{\circ} 12$, datedApril 11 2016. It makes public the decision not to incorporate the subdermal system ofetnogestrel $68 \mathrm{mg}$ for contraception in women aged 15 to 19 under the Unified Health System (2016) Official Journal of the Nation.

7. United Nation (2015) Trends in contraceptive use worldwide 2015. DepartmentofEconomicand Social Affairs, Population Division, USA, p. 63.

8. Ahmed S, Li Q Liu L, Tsui AO (2012) Maternal death saverted by contraceptive use: ananalysis of 172 countries (2012). The Lancet 380(9837): 111-125.

9. Cleland J, Conde-Agudelo A, Peterson H, Ross J, Tsui A (2012) Contraception and health (2012). The Lancet 380(9837): 149-156.

10. Brazil (2015) Brazilian Institute of Geography and Population Statistics National Health Survey 2013: lifecucles: Brazil and Major Regions. 
This work is licensed under Creative Commons Attribution 4.0 Licens DOI: 10.19080/JGWH.2017.02.555598

\section{Your next submission with Juniper Publishers} will reach you the below assets

- Quality Editorial service

- Swift Peer Review

- Reprints availability

- E-prints Service

- Manuscript Podcast for convenient understanding

- Global attainment for your research

- Manuscript accessibility in different formats

( Pdf, E-pub, Full Text, Audio)

- Unceasing customer service

Track the below URL for one-step submission https://juniperpublishers.com/online-submission.php 